\title{
Geographical distribution of stomach cancer in Czechoslovakia
}

\author{
O. GREGOR, R. TOMAN, F. PRUŠOVÁ, V. DRNKOVÁ, AND J. PASTOROVÁ \\ From the First Medical Clinic, University Hospital, the Research Institute of Trade, and the \\ Regional Medical Institute, Prague, Czechoslovakia
}

The mortality from stomach cancer is known to be very high, so we may consider the mortality rate one of the measures of its incidence.

Differences between continents and countries have been observed in the occurrence of stomach cancer (Doll, 1956; Clemmesen and Nielsen, 1957; Wynder, Kmet, Dungal, and Segi, 1963; Segi and Kurihara, 1966; Backett, 1967; Langman, 1967a, b). Segi and Kurihara compared the mortality rates from stomach cancer in 24 countries (1962-63), and report the highest mortality rates in Japan and in Chile, followed by those in Finland, Austria, West Germany. Low mortality rates from stomach cancer are reported in New Zealand, somewhat lower in Australia, and the lowest in the white population of the United States of America.

Some epidemiological studies have revealed differences in the incidence of stomach cancer within countries also, eg, in Great Britain, the United States of America, Japan, Norway, Denmark, Holland, Roumania (Legon, 1951; Davies and Wynne Griffiths, 1954; Tromp, 1956; Haenszel, 1958; Segi and Kurihara, 1960; Stocks and Davies, 1960; Pedersen and Magnus, 1961; Saxén, 1961; Kurokawa, 1964; Mork, 1954; Gregor, Toman, Pastorová, and Drnková, 1967).

The differences in geographical distribution have been correlated with certain environmental factors, eg, climatic conditions (lower or higher altitude or latitude) (Haenszel, 1958; Segi and Kurihara, 1960; Wynder et al, 1963), the physical and chemical nature of the soil, eg, humidity, acidity, trace elements, organic content (Legon, 1951; Davies and Wynne Griffiths, 1954; Tromp, 1955; Stocks and Davies, 1960; Millar, 1961), radioactive content of drinking water (Pedersen and Magnus, 1961), dietary and cooking habits (Segi and Kurihara, 1960; Dungal, 1961; Saxén, 1961; Wynder et al, 1963; Acheson and Doll, 1964; Higginson, 1966), and also with genetic factors, eg, susceptibility in different ethnic groups living in the same country (Ashley and Davies, 1966).

This paper deals with studies of three problems:
(1) the geographical distribution of deaths due to stomach cancer in Czechoslovakia in 1963; (2) a comparison of stomach cancer death rates and their regional differences with those of bronchopulmonary cancer; (3) the relation of regional stomach cancer mortality rates to food and alcohol consumption and to the number of male smokers in individual regions.

\section{MATERIALS AND METHODS}

The information used was mortality data (Population Shifting in the Czechoslovak Socialist Republic in 1963), food consumption balances (Analysis of Standard of Living in Regions of Czechoslovakia in 1964), and family budgets (Czechoslovak Family Budgets in 1963), and the results of a special inquiry into the frequency of smokers carried out in the context of family budgets (Strnadová and Špačková, 1966).

Czechoslovakia is divided into 11 regions, one of them being Prague, the capital (Table I and Fig. 1). For the purpose of this study the deaths due to stomach cancer and bronchopulmonary cancer, arranged according to sex and age, were tabulated according to individual regions. The number of deaths from each malignancy was compared with the number of all cancer deaths in each region and the corresponding percentages were calculated. The average stomach and bronchopulmonary cancer mortality rates in the whole country, and in each region separately, for males and females, were computed. The mortality rates were standardized according to age, and the sex ratio was calculated. The standardized mortality ratios for each malignancy were expressed as the ratio of the observed age-specific mortality rates in each region to the mortality rates expected from the rates for the country as a whole, multiplied by a hundred (Tables I and II).

We compared the numbers of deaths, the percentage of all cancer deaths, the age-specific and age-adjusted mortality rates, and the male : female ratio for stomach cancer with the corresponding figures for bronchopulmonary cancer.

Stomach cancer mortality rates were compared with data on regional food and alcohol consumption and with the percentage of male smokers in order to find out whether any correlations exist. Information on regional 


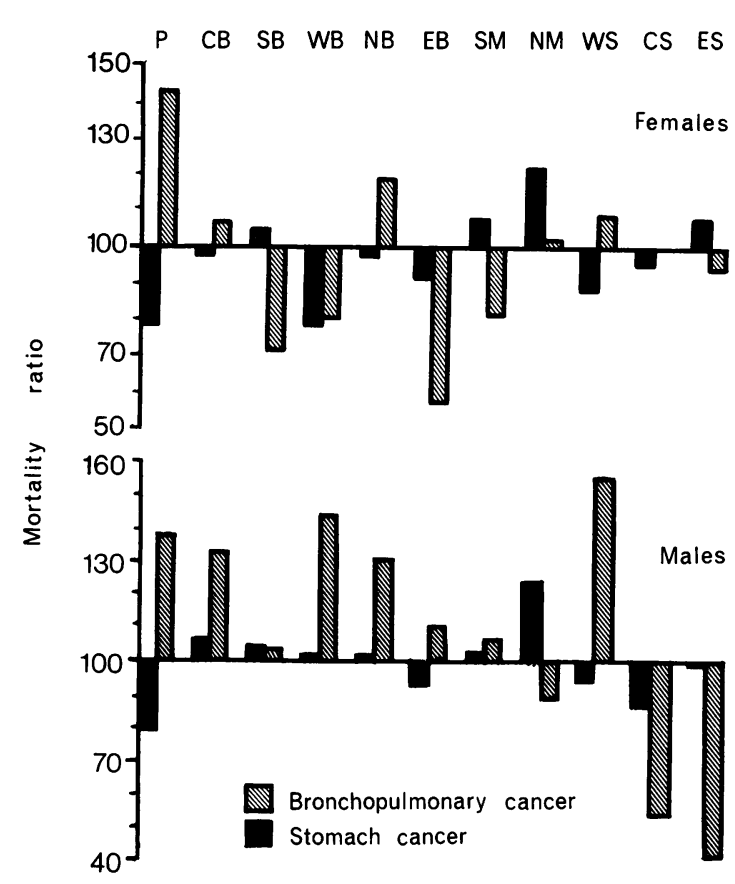

FIG. 1. Standardized mortality ratios for stomach cancer and bronchopulmonary cancer in males by regions in Czechoslovakia in 1963. $\mathrm{P}=$ Prague, $\mathrm{CB}=$ central Bohemia, $\mathrm{SB}=$ south Bohemia, $\mathrm{WB}=$ west Bohemia, $\mathrm{NB}=$ north Bohemia, $\mathrm{EB}=$ east Bohemia, $\mathrm{SM}=$ south Moravia, $\mathrm{NM}=$ north Moravia, WS $=$ west Slovakia, $\mathrm{CS}=$ central Slovakia, ES=east Slovakia.

differences in food consumption was drawn from the regional food consumption balances (Analysis of Standard of Living in Regions of Czechoslovakia in 1964), on which the average daily caloric value and the percentage of main nutrients were calculated (Table III), and from the statistics of family budgets (Czechoslovak Family Budgets in 1963), which are kept in about 9,000 households more or less proportionally distributed among all social groups in the 11 regions. These family budgets provided regional data not only on food but also on alcohol consumption, as well as data on regional rates of smokers (cigarette, cigar, and pipe smokers together) on the basis of a special inquiry (Strnadová and Spačková, 1966).

\section{RESULTS}

Deaths from stomach cancer amounted to 6,026 in 1963 (3,534 for males and 2,492 for females) which was $22 \%$ of all cancer deaths in Czechoslovakia (Table I). The percentage for females was 17.2 lower than that for males. The average mortality rate from stomach cancer was 51.72 for males and 34.75 for females (Table I).

The highest percentage of all cancer deaths due to stomach cancer, for both sexes together, was found in east $(29.1 \%)$ and central Slovakia $(26 \%)$ and in north Moravia (26.5\%); the lowest was observed in Prague $(13.9 \%)$ (Table I). The geographical differences in the occurrence of stomach cancer in different regions of Czechoslovakia, expressed as a standardized mortality ratio separately for both sexes, are shown in Figure 2. The highest stomach cancer mortality rates for both males and females were found in north Moravia and the lowest in Prague. A significantly lower ratio (less than 90) was also observed in west Bohemia and west Slovakia for females and in central Slovakia for males (Fig. 2). Differences were found also in regional male: female ratios for stomach cancer (Table I).

Deaths from bronchopulmonary cancer amounted to 5,041 in 1963 (4,480 for males and 561 for females) which was $18 \%$ of all cancer deaths in Czechoslovakia (Table II). The percentage for females was $\mathbf{7 7 . 8}$ lower than that for males. The average mortality rate from bronchopulmonary cancer was 65.56 in males and 7.82 in females. The geographical differences in the occurrence of bronchopulmonary

TABLE I

STOMACH CANCER MORTALITY RATES BY REGIONS IN CZECHOSLOVAKIA IN 1963

\begin{tabular}{|c|c|c|c|c|c|c|c|c|c|}
\hline \multirow[t]{2}{*}{$\begin{array}{l}\text { Ranking } \\
\text { No. }\end{array}$} & \multirow[t]{2}{*}{ Region } & \multirow{2}{*}{$\begin{array}{l}\text { Stomach } \\
\text { Cancer as } \\
\text { Percentage } \\
\text { of All } \\
\text { Cancer Deaths }\end{array}$} & \multicolumn{2}{|c|}{$\begin{array}{l}\text { Observed } \\
\text { Mortality } \\
\text { Rates }\end{array}$} & \multicolumn{2}{|c|}{$\begin{array}{l}\text { Age-adjusted } \\
\text { Mortality } \\
\text { Rates }\end{array}$} & \multirow{2}{*}{$\begin{array}{l}\text { Index } \\
\text { of Male: } \\
\text { Female } \\
\text { Ratio }\end{array}$} & \multicolumn{2}{|c|}{$\begin{array}{l}\text { Standardized } \\
\text { Mortality } \\
\text { Ratio }\end{array}$} \\
\hline & & & $\boldsymbol{M}$ & $F$ & $M$ & $F$ & & $M$ & $F$ \\
\hline 1 & Prague & $13 \cdot 9$ & $48 \cdot 64$ & $32 \cdot 84$ & $40 \cdot 86$ & $27 \cdot 28$ & $1 \cdot 52$ & 79 & 78 \\
\hline 2 & Central Bohemia & $20 \cdot 8$ & $69 \cdot 73$ & $44 \cdot 02$ & $55 \cdot 34$ & 33.67 & 1.64 & 107 & 97 \\
\hline 3 & South Bohemia & $22 \cdot 4$ & 63.01 & $44 \cdot 34$ & $54 \cdot 31$ & 36.49 & $1 \cdot 50$ & 105 & 105 \\
\hline 4 & West Bohemia & $20 \cdot 4$ & $50 \cdot 26$ & $38 \cdot 20$ & $52 \cdot 75$ & 26.97 & 1.96 & 102 & 78 \\
\hline 5 & North Bohemia & $19 \cdot 3$ & $45 \cdot 54$ & $28 \cdot 52$ & $52 \cdot 75$ & $33 \cdot 60$ & $1 \cdot 60$ & 102 & 97 \\
\hline 6 & East Bohemia & $20 \cdot 7$ & $56 \cdot 59$ & $38 \cdot 62$ & $47 \cdot 58$ & $31 \cdot 62$ & $1 \cdot 50$ & 92 & 91 \\
\hline 7 & South Moravia & $24 \cdot 0$ & $59 \cdot 10$ & $41 \cdot 50$ & $53 \cdot 27$ & $37 \cdot 39$ & $1 \cdot 43$ & 103 & 108 \\
\hline 8 & North Moravia & $26 \cdot 5$ & $57 \cdot 11$ & $37 \cdot 74$ & $64 \cdot 13$ & $42 \cdot 26$ & $1 \cdot 52$ & 124 & 122 \\
\hline 9 & West Slovakia & $22 \cdot 7$ & $44 \cdot 31$ & $25 \cdot 89$ & $48 \cdot 62$ & $30 \cdot 70$ & $1 \cdot 58$ & 94 & 88 \\
\hline 10 & Central Slovakia & $26 \cdot 0$ & $37 \cdot 74$ & 26.96 & $\mathbf{4 4 . 4 8}$ & $32 \cdot 84$ & $1 \cdot 34$ & 86 & 95 \\
\hline 11 & East Slovakia & $29 \cdot 1$ & $38 \cdot 59$ & $27 \cdot 02$ & $51 \cdot 20$ & $37 \cdot 46$ & $1 \cdot 37$ & 99 & 108 \\
\hline & All Czechoslovakia & $22 \cdot 0$ & $51 \cdot 32$ & 34.75 & $51 \cdot 32$ & $34 \cdot 75$ & $1 \cdot 48$ & 100 & 100 \\
\hline
\end{tabular}



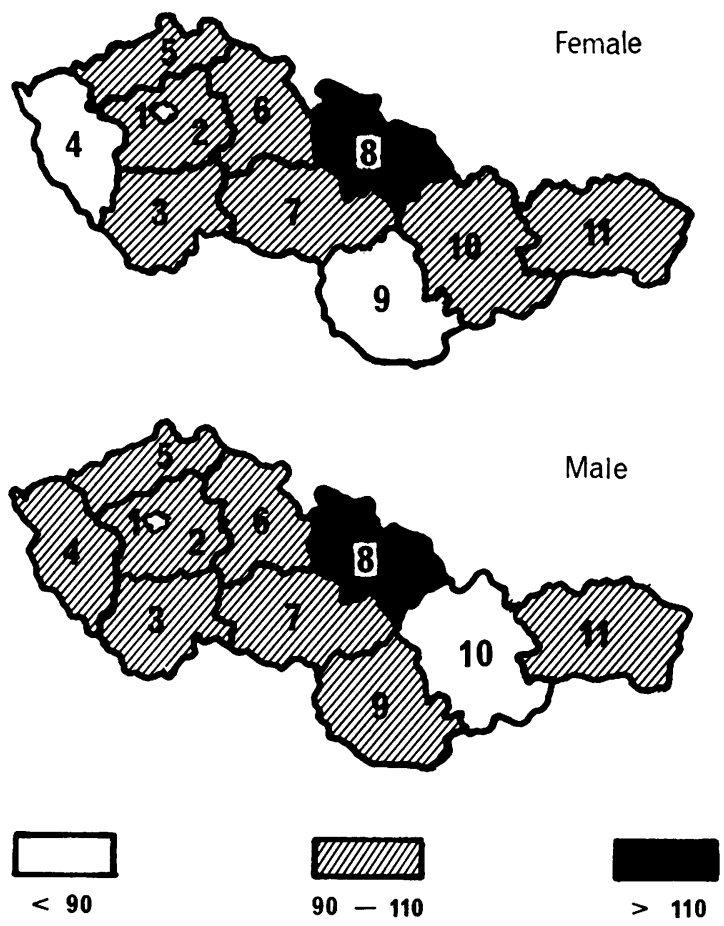

FIG. 2. Maximum and minimum age-adjusted mortality rates for stomach cancer in Czechoslovakia in 1963 by sex and by regions.

cancer in different regions, expressed as standardized mortality ratios, are illustrated separately for each sex in Figure 2.

The patterns of regional differences in age-adjusted mortality rates from stomach cancer do not correspond to those from bronchopulmonary cancer (Fig. 2).

Significant differences in the nutrient composition of the diet, as calculated from the regional food consumption balances, were found in six regions but they do not correspond to regional differences in standardized stomach cancer mortality rates (Table III). The nutrient composition of the diet, as derived from the statistics of family budgets, shows no significant differences among different regions, except in Prague where a lower proportion of carbohydrate is consumed (Table IV).

Regional differences in stomach cancer mortality rates showed no correlation with those of total alcohol consumption (beer, wine, and spirits together). Nor was there any statistically significant correlation with the data for consumption of spirits only (Table V). The coefficient of correlation by Pearson is $0 \cdot 14$ which is not significant.

An analysis of smoker frequency was done for males and showed a significantly lower rate in south Moravia and a significantly higher one in east Slovakia. Regional differences in stomach cancer mortality rates, however, do not correspond to those found in male smoker frequency (Table V).

\section{DISCUSSION}

According to stomach cancer mortality tables (1960-61) Czechoslovakia is sixth after Japan, Chile, Finland, Austria, and Hungary (Segi and Kurihara, 1966). Czechoslovakia's immediate neighbours are both the German republics, Poland, the Soviet Union, Hungary, and Austria. It is interesting to note that the central European countries-Austria, Hungary, Poland, and Germany-have also very high stomach cancer mortality rates.

Within Czechoslovakia we found regional differences in age-adjusted stomach cancer mortality rates (Fig. 2). Prague, the capital of Czechoslovakia, has the lowest mortality of the whole country, $36 \%$ lower than the region with the highest mortality (northern

TABLE II

BRONCHOPULMONARY CANCER MORTALITY RATES BY REGIONS IN CZECHOSLOVAKIA IN 1963

\begin{tabular}{|c|c|c|c|c|c|c|c|c|}
\hline \multirow[t]{2}{*}{ Region } & \multirow{2}{*}{$\begin{array}{l}\text { Bronchopulmonary } \\
\text { Cancer as } \\
\text { Percentage of } \\
\text { All Cancer Deaths }\end{array}$} & \multicolumn{2}{|c|}{$\begin{array}{l}\text { Observed } \\
\text { Mortality } \\
\text { Rates }\end{array}$} & \multicolumn{2}{|c|}{$\begin{array}{l}\text { Age-adjusted } \\
\text { Mortality } \\
\text { Rates }\end{array}$} & \multirow{2}{*}{$\begin{array}{l}\text { Index } \\
\text { of Male: } \\
\text { Female } \\
\text { Ratio }\end{array}$} & \multicolumn{2}{|c|}{$\begin{array}{l}\text { Standardized } \\
\text { Mortality } \\
\text { Ratio }\end{array}$} \\
\hline & & $M$ & $F$ & $M$ & $F$ & & $M$ & $F$ \\
\hline Prague & $20 \cdot 7$ & $111 \cdot 59$ & $14 \cdot 10$ & $90 \cdot 47$ & $11 \cdot 18$ & $8 \cdot 10$ & 138 & 143 \\
\hline Central Bohemia & $21 \cdot 6$ & $109 \cdot 40$ & 10.96 & $87 \cdot 19$ & $8 \cdot 37$ & $10 \cdot 40$ & 133 & 107 \\
\hline South Bohemia & $17 \cdot 3$ & $77 \cdot 88$ & 6.59 & $68 \cdot 18$ & $5 \cdot 55$ & $12 \cdot 30$ & 104 & 71 \\
\hline West Bohemia & $22 \cdot 0$ & $90 \cdot 43$ & $6 \cdot 26$ & $94 \cdot 41$ & $6 \cdot 26$ & $15 \cdot 10$ & 144 & 80 \\
\hline North Bohemia & $23 \cdot 0$ & $80 \cdot 58$ & $8 \cdot 38$ & $85 \cdot 23$ & $9 \cdot 30$ & $9 \cdot 18$ & 130 & 119 \\
\hline East Bohemia & $19 \cdot 2$ & $85 \cdot 06$ & $5 \cdot 47$ & $72 \cdot 12$ & $4 \cdot 46$ & $16 \cdot 20$ & 110 & 57 \\
\hline South Moravia & $16 \cdot 1$ & $61 \cdot 79$ & $7 \cdot 19$ & $70 \cdot 15$ & $6 \cdot 33$ & $11 \cdot 20$ & 107 & 81 \\
\hline North Moravia & $16 \cdot 3$ & $51 \cdot 44$ & $7 \cdot 50$ & 57.69 & $7 \cdot 98$ & $7 \cdot 12$ & 88 & 102 \\
\hline West Slovakia & $17 \cdot 2$ & $46 \cdot 10$ & $7 \cdot 54$ & $102 \cdot 27$ & $8 \cdot 52$ & $12 \cdot 00$ & 156 & 109 \\
\hline Central Slovakia & $14 \cdot 4$ & $29 \cdot 32$ & 6.66 & $34 \cdot 75$ & $7 \cdot 82$ & $4 \cdot 43$ & 53 & 100 \\
\hline East Slovakia & $11 \cdot 5$ & $20 \cdot 43$ & $5 \cdot 64$ & $6 \cdot 88$ & $7 \cdot 35$ & $3 \cdot 65$ & 41 & 94 \\
\hline All Czechoslovakia & 18.4 & $65 \cdot 56$ & $7 \cdot 82$ & 556 & $7 \cdot 82$ & $8 \cdot 40$ & 100 & 100 \\
\hline
\end{tabular}


TABLE III

NUTRIENT COMPOSITION OF THE CALORIC INTAKE BY REGIONS

\begin{tabular}{|c|c|c|c|c|c|}
\hline Region & $\begin{array}{l}\text { Calories } \\
\text { per Day }\end{array}$ & $\begin{array}{l}\text { Percentage } \\
\text { of Proteins }\end{array}$ & $\begin{array}{l}\text { Percentage } \\
\text { of Animal } \\
\text { Proteins }\end{array}$ & $\begin{array}{l}\text { Percentage } \\
\text { of Fats }\end{array}$ & $\begin{array}{l}\text { Percentage } \\
\text { of } \\
\text { Carbohydrates }\end{array}$ \\
\hline Prague & 2,790 & $11 \cdot 7$ & $6 \cdot 7$ & $38 \cdot 3$ & $50 \cdot 0$ \\
\hline Central Bohemia & 3,060 & $10 \cdot 8$ & $5 \cdot 5$ & $33 \cdot 1$ & $56 \cdot 1$ \\
\hline South Bohemia & 3,283 & $11 \cdot 0$ & $5 \cdot 6$ & $31 \cdot 6$ & $57 \cdot 4$ \\
\hline West Bohemia & 3,116 & $11 \cdot 3$ & $5 \cdot 9$ & $33 \cdot 7$ & $55 \cdot 0$ \\
\hline North Bohemia & 3,146 & $11 \cdot 1$ & $6 \cdot 0$ & $36 \cdot 3$ & $52 \cdot 6$ \\
\hline South Moravia & 3,070 & $10 \cdot 7$ & $5 \cdot 5$ & $32 \cdot 1$ & $57 \cdot 2$ \\
\hline North Moravia & 3,136 & $10 \cdot 9$ & $5 \cdot 8$ & $34 \cdot 8$ & $54 \cdot 3$ \\
\hline West Slovakia & 2,880 & $10 \cdot 9$ & $5 \cdot 0$ & $26 \cdot 6$ & $62 \cdot 5$ \\
\hline Central Slovakia & 2,942 & $11 \cdot 2$ & $5 \cdot 2$ & $27 \cdot 7$ & $61 \cdot 1$ \\
\hline East Slovakia & 2,866 & $10 \cdot 9$ & $4 \cdot 6$ & $26 \cdot 9$ & $62 \cdot 2$ \\
\hline All Czechoslovakia & 3,134 & $11 \cdot 2$ & $5 \cdot 4$ & $30 \cdot 7$ & $58 \cdot 1$ \\
\hline
\end{tabular}

Calculated from food consumption balances.

TABLE IV

NUTRIENT COMPOSITION OF THE CALORIC INTAKE BY REGIONS

\begin{tabular}{|c|c|c|c|c|c|}
\hline Region & $\begin{array}{l}\text { Kilo-calories } \\
\text { per Head } \\
\text { Yearly }\end{array}$ & $\begin{array}{l}\text { Percentage } \\
\text { of Meat, } \\
\text { Milk and Eggs }\end{array}$ & $\begin{array}{l}\text { Percentage } \\
\text { of Fats }\end{array}$ & $\begin{array}{l}\text { Percentage } \\
\text { of Sugar, Sweets, } \\
\text { Potatoes, Cereals }\end{array}$ & $\begin{array}{l}\text { Percentage } \\
\text { of Vegetables } \\
\text { and Fruit }\end{array}$ \\
\hline Prague & $836 \cdot 7$ & $27 \cdot 0$ & $17 \cdot 3$ & $48 \cdot 1$ & $7 \cdot 6$ \\
\hline Central Bohemia & $1015 \cdot 6$ & $23 \cdot 6$ & $15 \cdot 4$ & $54 \cdot 1$ & 6.9 \\
\hline South Bohemia & $983 \cdot 2$ & $26 \cdot 0$ & $13 \cdot 8$ & $54 \cdot 3$ & $5 \cdot 9$ \\
\hline West Bohemia & $928 \cdot 7$ & $26 \cdot 2$ & $15 \cdot 1$ & $52 \cdot 7$ & 6.0 \\
\hline North Bohemia & $954 \cdot 1$ & $24 \cdot 5$ & $16 \cdot 4$ & $51 \cdot 8$ & $7 \cdot 3$ \\
\hline East Bohemia & $969 \cdot 8$ & $25 \cdot 2$ & $15 \cdot 6$ & $52 \cdot 0$ & $7 \cdot 2$ \\
\hline South Moravia & $968 \cdot 3$ & $26 \cdot 0$ & $15 \cdot 0$ & $53 \cdot 2$ & $5 \cdot \overline{8}$ \\
\hline North Moravia & $945 \cdot 2$ & $26 \cdot 9$ & $16 \cdot 1$ & $50 \cdot 2$ & 6.8 \\
\hline West Slovakia & $893 \cdot 7$ & $24 \cdot 5$ & $14 \cdot 2$ & $54 \cdot 1$ & $6 \cdot 2$ \\
\hline Central Slovakia & $876 \cdot 1$ & $24 \cdot 0$ & $15 \cdot 4$ & $55 \cdot 4$ & $5 \cdot 2$ \\
\hline East Slovakia & $884 \cdot 6$ & $22 \cdot 4$ & $15 \cdot 8$ & $56 \cdot 1$ & $5 \cdot 7$ \\
\hline All Czechoslovakia & 936.6 & $24 \cdot 8$ & $15 \cdot 3$ & $53 \cdot 5$ & $6 \cdot 4$ \\
\hline
\end{tabular}

On the basis of family budgets.

TABLE V

CONSUMPTION OF SPIRITS PER HEAD AND PERCENTAGE OF MALESMOKERS AND AGE-ADJUSTED STOMACH CANCER MORTALITY RATES BY REGIONS

\begin{tabular}{llll} 
Region & $\begin{array}{l}\text { Spirits } \\
\text { per Head }(l .)\end{array}$ & $\begin{array}{l}\text { Percentage } \\
\text { of } \\
\text { Male Smokers }\end{array}$ & $\begin{array}{l}\text { Age-adjusted } \\
\text { Stomach Cancer } \\
\text { Mortality Rates } \\
\text { in Males }\end{array}$ \\
\hline Prague & & 42 & $40 \cdot 86$ \\
Central Bohemia & 0.20 & 39 & $55 \cdot 34$ \\
South Bohemia & 0.55 & 38 & $54 \cdot 31$ \\
West Bohemia & 0.60 & 44 & $52 \cdot 75$ \\
North Bohemia & 0.54 & 44 & 52.75 \\
East Bohemia & 0.63 & 39 & $47 \cdot 58$ \\
South Moravia & 0.50 & 34 & $53 \cdot 27$ \\
North Moravia & 1.06 & 40 & $64 \cdot 13$ \\
West Slovakia & 0.82 & 43 & 48.62 \\
Central Slovakia & 1.38 & 42 & 44.48 \\
East Slovakia & 1.50 & 45 & $51 \cdot 20$ \\
All Czechoslovakia & 0.76 & 41 & $51 \cdot 32$
\end{tabular}

On the basis of statistics for family budgets.

Moravia) and $26 \%$ lower than the region of its immediate surroundings (central Bohemia). We compared these regional differences for 1963 with those reported by Gregor for 1959 (Gregor, 1965), and found that they are on the whole the same. We have therefore assumed that these geographical differences within the country have been constant at least over this period of five years.

To find out whether these geographical differences are not only constant but also real we eliminated the distorting influence of the different age distribution (Table I). Moreover it seems that the reliability of diagnosis in the individual regions was roughly the same over the period studied. We may therefore consider these differences within the country to be real.

We compared the standardized mortality rate for stomach cancer with that for bronchopulmonary cancer in individual regions and found convincing differences.

We may therefore assume that there are certain different environmental factors specific to each of these two cancer sites, stomach and lung.

Having found convincing geographical differences for the incidence of stomach cancer in Czechoslovakia, we tried to compare them with some of the environmental factors which might perhaps be of 
some pathogenetical importance: food and alcohol consumption as well as tobacco smoking. Inquiries into the diets of individual stomach cancer patients and of a comparative group large enough for statistical evaluation are time-consuming and require a large team of investigators. Moreover the energy given to such a task is enormous and the results very modest (Wynder et al, 1963; Acheson and Doll, 1964; Higginson, 1966). We therefore compared the stomach cancer mortality rates in different regions in Czechoslovakia with the actual consumption of proteins, fats, carbohydrates, and alcohol as well as with the numbers of male smokers in these regions. No statistically significant correlation was found. The only exception was the capital, Prague, which has the lowest stomach cancer mortality rate, and, at the same time, the lowest carbohydrate consumption (Tables I and III). We are aware that we did not analyse male and female smokers separately. We did not differentiate them into cigarette, cigar, and pipe smokers, nor did we consider the intensity of smoking in time and quantity. We are not drawing any firm conclusions and are therefore considering these findings as illustrative only, and, as the percentage of female smokers was only 5 whereas for males it was 41 , we correlated the respective rates for males only.

\section{SUMMARY}

Stomach cancer in Czechoslovakia causes about $22 \%$ of all cancer deaths. The average stomach cancer mortality rate is 51.72 for males and 34.75 for females. According to standardized mortality rates (42.78 for males and 22.33 for females in 1963) Czechoslovakia should occupy the fifth place in the table of 24 countries (1962-63) arranged by Segi and Kurihara (1966).

Significant geographical differences in age-adjusted and sex-specific stomach cancer mortality rates were found in some regions in Czechoslovakia, the differences between the highest (north Moravia) and lowest (Prague) being 36\%. Another noteworthy difference $(26 \%)$ was found to be between Prague and its immediate surroundings (central Bohemia region).

Regional differences in age-adjusted and sexspecific mortality rates from stomach cancer in Czechoslovakia are real and remained constant over the period 1959-63. As they do not correspond to the regional differences for bronchopulmonary cancer we may assume that there is certain environmental factors specific for these two sites.

The geographical distribution pattern for stomach cancer in Czechoslovakia does not correspond with any actual regional differences in food and alcohol consumption or with the percentage of male smokers.

\section{REFERENCES}

Acheson, E. D., and Doll, R. (1964). Dietary factors in carcinoma of the stomach: a study of 100 cases and 200 controls. Gut, 5, 128-131.

Ashley, D. J. B., and Davies, H. D. (1966). Gastric cancer in Wales. Gut, 7, 542-548.

Backett, E. M. (1967). The Epidemiology of Gastric Cancer. Working Group, Copenhagen, January 1967.

Czechoslovakia, General Bureau of State Control and Statistics (1966). Analysis of Standard of Living in Regions of Czechoslovakia in 1964, Prague.

_- General Bureau of State Control and Statistics. Czechoslovak Family Budgets in 1963. Prague.

- General Bureau of State Control and Statistics. Manuscript Material for the year 1963. Prague.

Clemmesen, J., and Nielsen, A. (1957). Comparison of age-adjusted cancer incidence rates in Denmark and United States. J. nat. Cancer Inst., 19, 989-998.

Davies, R. I., and Griffith, G. W. (1954). Cancer and soils in the county of Anglesey. Brit. J. Cancer, 8, 56-66.

Doll, R. (1956). Environmental factors in the aetiology of cancer of the stomach. Gastroenterologia (Basel), 86, 320-328.

Dungal, N. (1961). Can smoked food be carcinogenic? Acta Un. int. Cancr., 17, 365-366.

- - General Bureau of State Control and Statistics. Population Shifting in the Czechoslovak Socialist Republic in 1963. Prague.

Gregor, O. (1965). Early Diagnosis of Cancer of the Stomach. Prague.

-, Toman, R., Pastorová, J., and Drnková, V. (1967). Epidemiology of cancer of the stomach and other parts of the alimentary tract. In Proc. 3rd Wld. Congr. Gastro-ent. Recent Advances in Gastroenterology, vol. 1, pp. 84-92. Tokyo.

Haenszel, W. (1958). Yariation in incidence of and mortality from stomach cancer, with particular reference to the United States. J. nat. Cancer Inst., 21, 213-262.

Higginson, J. (1966). Etiological factors in gastrointestinal cancer in man. Ibid., 37, 527-545.

Kurokawa, T. (1964). Stomach cancer in Japan, Acta Un. int. Cancr. 20, 790-792.

Langman, M. J. S. (1967a). The stomach: epidemiological considerations. In The Prevention of Cancer, pp. 99-102. Edited by R. W. Raven and F. J. C. Roe: Butterworths, London.

- , (1967b). The epidemiology of gastrointestinal cancer. Gut, 8, 315-317.

Legon, C. D. (1951). A note on geographical variations in cancer mortality, with special reference to gastric cancer in Wales. Brit.J. Cancer, 5, 175-179.

Millar, I. B. (1961). Gastro-intestinal cancer and geochemistry in North Montgomeryshire. Brit. J. Cancer, 15, 175-199.

Mork, T. (1964). On the geographical distribution of carcinoma of the stomach in Norway. Acta Un. int. Cancr., 20, 626-628.

Pedersen, E., and Magnus, K. (1961). Gastro-intestinal cancer in Norway. Ibid., 17, 373-379.

Saxén, E. (1961). Gastro-intestinal cancer in Finland. Ibid., 17, 367-372.

Segi, M., and Kurihara, M. (1960). Cancer in Japan from the viewpoint of geographical pathology. Tohoku J. exp. Med., 72, 169-193.

- - (1966). Cancer Mortality for Selected Sites in 24 Countries (1962-1963). Department of Public Health, Tohoku University School of Medicine, Sendai, Japan.

Stocks, P., and Davies, R. I. (1960). Investigation of a localized high incidence of gastric cancer. Publ. Hlth. (Lond.), 74, 408-412.

Strnadová, M., and Špačková, I. (1966). Long Range Perspective of Smoking. Study of the Research Institute of Home Trade, Prague.

Tromp, S. W. (1955). Possible effects of geophysical and geochemical factors on development and geographic distribution of cancer. Schweiz. Z. allg. Path., 18, 929-939.

-, (1956). The geographical distribution of cancer of the stomach in the Netherlands (period 1946-1952). Brit. J. Cancer, 10, 265-281.

Wynder, E. K., Kmet, J., Dungal, N., and Segi, M. (1963). An epidemiological investigation of gastric cancer. Cancer (Philad.), 16, 1461-1496. 